\title{
Glucocorticoid treatment and endocrine pancreas function: implications for glucose homeostasis, insulin resistance and diabetes
}

\author{
Alex Rafacho', Henrik Ortsäter ${ }^{2}$, Angel Nadal ${ }^{3}$ and Ivan Quesada ${ }^{3}$ \\ ${ }^{1}$ Department of Physiological Sciences, Center of Biological Sciences, Federal University of Santa Catarina (UFSC), \\ 88040-900, Florianópolis, SC, Brazil \\ ${ }^{2}$ Department of Clinical Science and Education, Södersjukhuset, Karolinska Institutet, SE-11883 Stockholm, Sweden \\ ${ }^{3}$ Institute of Bioengineering and the Biomedical Research Center in Diabetes and Associated Metabolic Disorders \\ (CIBERDEM), Miguel Hernández University, University Avenue s/n, 03202, Elche, Spain
}

Correspondence should be addressed to A Rafacho or I Quesada Emails

alex.rafacho@ufsc.br or ivanq@umh.es

\begin{abstract}
Glucocorticoids (GCs) are broadly prescribed for numerous pathological conditions because of their anti-inflammatory, antiallergic and immunosuppressive effects, among other actions. Nevertheless, GCs can produce undesired diabetogenic side effects through interactions with the regulation of glucose homeostasis. Under conditions of excess and/or long-term treatment, GCs can induce peripheral insulin resistance (IR) by impairing insulin signalling, which results in reduced glucose disposal and augmented endogenous glucose production. In addition, GCs can promote abdominal obesity, elevate plasma fatty acids and triglycerides, and suppress osteocalcin synthesis in bone tissue. In response to GC-induced peripheral IR and in an attempt to maintain normoglycaemia, pancreatic $\beta$-cells undergo several morphofunctional adaptations that result in hyperinsulinaemia. Failure of $\beta$-cells to compensate for this situation favours glucose homeostasis disruption, which can result in hyperglycaemia, particularly in susceptible individuals. GC treatment does not only alter pancreatic $\beta$-cell function but also affect them by their actions that can lead to hyperglucagonaemia, further contributing to glucose homeostasis imbalance and hyperglycaemia. In addition, the release of other islet hormones, such as somatostatin, amylin and ghrelin, is also affected by GC administration. These undesired GC actions merit further consideration for the design of improved GC therapies without diabetogenic effects. In summary, in this review, we consider the implication of GC treatment on peripheral IR, islet function and glucose homeostasis.
\end{abstract}

\section{Key Words \\ - glucocorticoids \\ - insulin resistance \\ - insulin sensitivity \\ - insulin secretion \\ - glucagon secretion \\ - glucose tolerance \\ - diabetes}

Journal of Endocrinology (2014) 223, R49-R62

\section{Introduction}

Glucocorticoids (GCs), such as cortisol in humans and corticosterone in rodents, are produced in the adrenal cortex and play a key role in the regulation of glucose homeostasis and nutrient metabolism. Synthetic GCs, which include dexamethasone and prednisolone, are used in medical practice because of their anti-inflammatory, 
antiallergic and immunosuppressive effects. Although synthetic GCs are broadly prescribed in numerous pathological conditions, they have important adverse metabolic effects, including peripheral insulin resistance (IR) and glucose intolerance as well as overt hyperglycaemia and diabetes. These side effects are observed particularly in susceptible individuals such as pregnant women, obese subjects, IR individuals or first-degree relatives of diabetic patients (Van Raalte et al. 2009). The ability of GCs to produce peripheral IR is central to explain their impact on glucose homeostasis. It is well known that any reduction in peripheral insulin sensitivity, e.g., when GCs are administered, is adaptively compensated by augmented pancreatic $\beta$-cell function (Beard et al. 1984, Nicod et al. 2003, Ahrén 2008, Rafacho et al. 2008). This islet compensation meets the principle of the disposition index, the product of insulin secretion and peripheral insulin sensitivity. When $\beta$-cells fail to adjust to the insulin demand imposed by the GC treatment, fasting and/or postprandial hyperglycaemia may arise. The severity and progression of these alterations depend on several parameters including dosage, period and previous individual susceptibility among others (Novelli et al. 1999, Rafacho et al. 2008, Jensen et al. 2012). In addition to the islet's compensatory responses to IR, GCs directly affect $\beta$-cell function, which may further complicate adequate glycaemia regulation. Although less explored than insulin release, these steroids also affect the secretion of other islet hormones with important roles in glucose homeostasis, such as glucagon, somatostatin and amylin. All these alterations in islet hormonal secretion can exacerbate GCs' diabetogenic actions. In the next sections, we review the main effects of GCs on peripheral tissues and the endocrine pancreas and also consider the risks and limitations of their therapeutic use.

\section{Cellular mechanisms of GC action}

Ninety-five percent of circulating cortisol is bound to corticosteroid-binding globulins and albumin (Andrews \& Walker 1999). The plasma levels of the inactive form, cortisone, are $\sim 50-100 \mathrm{nM}$, and the hormone is largely unbound to plasma proteins (Walker et al. 1992). Local conversion between active and inactive forms is catalysed by $11 \beta$-hydroxysteroid dehydrogenase (11ß-HSD). $11 \beta$-HSD type 1 (11 $\beta$-HSD1) is a reductase that converts inactive cortisone (in humans) and 11-dehydrocorticosterone (in rodents) to active cortisol and corticosterone respectively (Low et al. 1994, Voice et al. 1996). The type 2 isoform works as a dehydrogenase that catalyses the opposite reaction (Brown et al. 1993). The actions of $11 \beta$-HSD1 and $11 \beta-H S D 2$ serve as a pre-receptor control of GC action and determine local GC concentrations.

GC action at the site of cells is activated by the steroid hormone binding to its receptor. The classical GC receptor (GR), a ligand-regulated transcription factor that belongs to the superfamily of nuclear receptors, binds GCs and regulates transcription of target genes by activation or repression (Mangelsdorf et al. 1995). The GR is expressed in virtually all tissues; however, GR is able to regulate genes in a cell-specific manner, indicating that the response to GCs is regulated by factors beyond receptor expression. The GR is guided from the moment of synthesis to decay through signal transduction and by a variety of molecular chaperones such as HSP70 (Nelson et al. 2004) and HSP90 (Pratt et al. 2006), which facilitate folding, maturation and ligand binding. In addition, GR-mediated transcriptional activation is modulated both positively and negatively by phosphorylation (Ismaili \& Garabedian 2004) of kinases and phosphatases. Although the activity of the GR is often thought in terms of direct gene transactivation, considerable crosstalk also occurs between the GR and a cohort of molecules to mediate their function as transcriptional factors, including octamer transcription factors, OCT1 and OCT2, cyclic adenosine monophosphate response element-binding protein and signal transducers and activators of transcription 5 (Engblom et al. 2007, Chen et al. 2012, Ratman et al. 2013). Competition for limiting transcription co-activators is an important determinant of the fate of the crosstalk between the GR and other transcription factors. In addition to these genomic GC actions, the steroid hormone can induce effects on a minute time scale, which is difficult to explain by mechanisms involving gene expression changes (Long et al. 2005). Localised cell membrane receptors with GC affinity have recently been identified (Strehl \& Buttgereit 2014).

\section{GC therapy in clinical practice}

Drugs based on GCs were introduced in the 1950s and have been an important therapeutic strategy to treat rheumatic and inflammatory diseases ever since. In this regard, the relevant properties are the immunosuppressive, antiinflammatory and antiallergic effects that GCs exert on primary and secondary immune cells, tissues and organs (Stahn \& Buttgereit 2008). Estimates suggest that between 1 and $2 \%$ of the adult population in the Western world is receiving some form of long-term GC treatment, with a clear higher usage among patients of the geriatric age group

Published by Bioscientifica Ltd 
(Van Staa et al. 2000). In dermatology, GCs are the most widely used therapy, for example, to treat atopic eczema. Inhaled GCs are used to treat allergic reactions in airways and to dampen bronchial hyperreactivity in asthma. Systemically, GCs are used to combat connective tissue inflammation, rheumatoid arthritis, bowel diseases and in allotransplantation (Thiele et al. 2005).

\section{Diabetogenic actions of GCs in skeletal muscle and adipose, hepatic and bone tissues}

There are a myriad of risks associated with excessive GC use; these risks have been recognised since GCs came into clinical use (Schäcke et al. 2002). Given GCs' strong capacity to counteract the action exerted by insulin and raise blood sugar levels, it is not surprising that IR and glucose intolerance is a concern in patients with Cushing's syndrome and disease (endogenous GC overproduction) and in patients prescribed GC-based therapy for immunomodulatory purposes (Raúl Ariza-Andraca et al. 1998). In addition, hypercortisolaemic conditions share many characteristics with metabolic syndrome, a cluster of abnormalities including hyperglycaemia, abdominal obesity, dyslipidaemia and hypertension (Anagnostis et al. 2009). Low-dose GC therapy is considered when the daily dose is $<7.5 \mathrm{mg}$ prednisolone or equivalent (van der Goes et al. 2010). When such a dose is administrated orally, plasma prednisolone levels peak $2-4 \mathrm{~h}$ after intake at about $400-500 \mathrm{nM}$ $(\sim 150-200 \mathrm{ng} / \mathrm{ml})$ and return to baseline within $12 \mathrm{~h}$ after steroid administration (Wilson et al. 1977, Tauber etal. 1984). These values are in the same range as normal endogenous cortisol levels: reference values for samples taken between 0400 and $0800 \mathrm{~h}$ are $250-750 \mathrm{nM}$ and for samples taken between 2000 and $2400 \mathrm{~h}$ are $50-300 \mathrm{nM}$. This indicates that the absolute cortisol values are not as important for developing adverse effects during low-dose GC therapy as is the diurnal variation. Current knowledge gives at hand that development of diabetes after starting low-dose GC treatment seems rare, but progression of already impaired glucose tolerance to overt diabetes is possible (van der Goes et al. 2010). Therefore, clinical recommendation states that baseline fasting glucose should be monitored before initiating therapy and during following up according to standard patient care. Certainly, the adverse effects are more pronounced during high-dose GC therapies $(>30 \mathrm{mg}$ prednisolone or equivalent daily). In a retrospective study of HbA1c levels in patients with rheumatic diseases subjected to prednisolone treatment, it was found that around 82\% had HbA1c levels higher than $48 \mathrm{mmol} / \mathrm{mol}$ (given in IFCC standard, corresponding to $6.7 \%$ in DCCT standard).
Serum HbA1c levels higher than $52 \mathrm{mmol} / \mathrm{mol}$ (7.1\%) were seen in $46 \%$ of the patients and $23 \%$ of the patients had $\mathrm{HbA1c}$ levels as high as $57 \mathrm{mmol} / \mathrm{mol}$ (7.6\%), which should be considered as a high-risk factor for diabetes. Taken together, it was found that the cumulative prednisolone dose was the only factor significantly associated with the development of steroid-induced diabetes among rheumatic patients (Origuchi et al. 2011).

\section{Adipose tissue}

GCs regulate the maturation of pre-adipose cells into differentiated adipose cells as well as metabolism in adipose tissue (Rebuffé-scrive et al. 1992). As the GR is predominantly expressed in adipose cells located in intraabdominal fat, GCs are more highly activated in these fat deposits (Pedersen et al. 1994). A striking feature observed under conditions of GC excess is enhanced accumulation of visceral fat and loss of peripheral fat deposits in the arms and legs (Reynolds et al. 2012; Fig. 1). In the peripheral fat deposits, GCs promote the expression of the key lipolytic enzyme hormone-sensitive lipase (Slavin et al. 1994); thus, acute infusion of cortisol in healthy humans induces triglyceride hydrolysis and the release of fatty acids and glycerol to the systemic circulation (Divertie et al. 1991). On the contrary, it has been suggested that GCs promote increased fat mass and triglyceride synthesis in visceral fat. Hence, GCs and insulin work in concert to activate lipoprotein lipase (Ottosson et al. 1994), which leads to relocation of fat deposits from arms and legs to abdominal sites. Furthermore, GC treatment was shown to inhibit $5^{\prime}$ AMP-activated protein kinase (AMPK) activity specifically in rat visceral, but not subcutaneous adipose tissue (Christ-Crain et al. 2008), which may explain the redistribution of fat deposits that occurs during GC excess. This hypothesis remains to be proven in humans but is supported by the observation that patients with Cushing's syndrome exhibited a 70\% lower AMPK activity in visceral adipose tissue (Kola et al. 2008). In Addition, GC-induced attenuation of insulin signalling in the adipose tissue has been associated with reduced glucose uptake (Ortsäter et al. 2012). In summary, GCs exposure leads to impaired insulin signalling and a systemic elevation of fatty acids and triglycerides which contributes to IR. Furthermore, GCs induce abdominal obesity.

\section{Skeletal muscle}

Skeletal muscle accounts for $\sim 80 \%$ of insulin-mediated glucose uptake (IMGU) and is the largest glycogen store.

Published by Bioscientifica Ltd. 


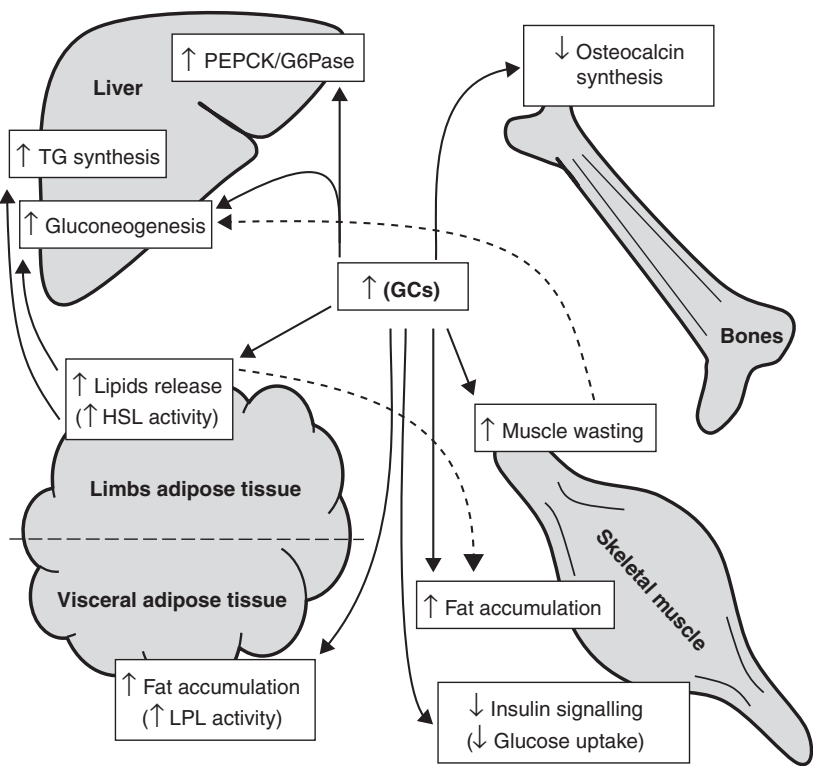

Figure 1

Effects of GCs on peripheral tissues involved in the control of glucose homeostasis. Excess or prolonged GC treatment may disrupt glucose homeostasis by interfering with several metabolic-related tissues. In visceral adipose tissue, GCs elevate LPL activity, leading to fat accumulation at this fat site. Fat in the limbs appears to respond to GCs with increased HSL activity, resulting in increased lipid (FFA and glycerol) release, supplying substrates for hepatic TG synthesis and gluconeogenesis, and also in intramuscular fat accumulation. These steroids may also affect insulin signalling in adipose tissue. GCs impair insulin-stimulated glucose uptake in skeletal muscles and induce muscle wasting, which, in turn, provides gluconeogenesis substrates. In the liver, GCs have a negative effect on rate-limiting enzymes controlled by insulin. Finally, GC in excess may also alter osteocalcin synthesis in osteoblast cells, leading to reduced osteocalcinaemia. FFA, free fatty acids; GCs, glucocorticoids; G6Pase, glucose-6-phospatase; HSL, hormone-sensitive lipase; LPL, lipoprotein lipase; PEPCK, phophoenolpyruvate carboxykinase; TG, triacylglycerol.

GCs interfere directly with insulin signalling in skeletal muscle cells. Studies have shown that administration of dexamethasone reduces the expression and activity of insulin substrate 1 (IRS1) and phosphatidylinositol-4,5bisphosphate 3-kinase in rodent skeletal muscle cells (Saad et al. 1993, Morgan et al. 2009), which would presumably lead to a reduction in IMGU and abrogation of glycogen synthesis (Fig. 1). Indeed, in a study with healthy human volunteers, prednisolone treatment for 6 days $(0.8 \mathrm{mg} / \mathrm{kg}$ per day) reduced insulin-induced leg glucose uptake by $65 \%$ compared with placebo treatment (Short et al. 2009). In a study supporting this, rats treated with GCs were shown to have reduced insulin-stimulated glucose uptake, caused by attenuated insulin-induced glucose transporter type 4 translocation to the cell membrane in myotubes (Dimitriadis et al. 1997). The condition is worsened by the accumulation of ectopic fat deposition in skeletal muscle (Fransson et al. 2013; Fig. 1), which originates from the systemic GC-induced fatty acid elevation as discussed earlier. Taken together, these data show that GCs directly interfere with insulin signalling in skeletal muscle cells leading to reduced IMGU.

\section{Hepatic tissue}

Hepatic tissue plays a key role in the control of glucose and lipid homeostasis. Although insulin does not directly stimulate glucose uptake in liver cells, the hormone is responsible for hepatic glycogen synthesis and gluconeogenesis suppression. These insulin actions are mediated via insulin receptor signalling. As in skeletal muscle, GC excess also interferes with the insulin signalling cascade in hepatic tissue. In one study, dexamethasone-treated rats $(1.5 \mathrm{mg} / \mathrm{kg}$ body weight for 6 consecutive days) exhibited an $\sim 50-70 \%$ reduction in insulin receptor binding in hepatocytes (Olefsky et al. 1975). A significant reduction in insulin receptor density was also observed in hepatocytes from rats chronically treated with dexamethasone (Caro \& Amatruda 1982). Diminished tyrosine phosphorylation in either insulin receptor or IRS1 was observed in liver from rats treated with dexamethasone for 5 consecutive days (Saad et al. 1993). In addition, GCs were shown to augment endogenous glucose production in several (Rizza et al. 1982, Pagano et al. 1983, Rooney et al. 1993) but not all (Wajngot et al. 1990) studies conducted in healthy humans. GC-driven glucose production may be caused by enhanced gluconeogenesis, as GCs induce rate-limiting enzymes for gluconeogenesis, e.g., phosphoenolpyruvate carboxykinase and glucose-6-phosphatase (Lange et al. 1994, Cassuto et al. 2005; Fig. 1). GC-mediated expression of gluconeogenic enzymes appears to be dependent on liver X receptor (LXR) expression (Patel et al. 2011). Indeed, mice lacking LXR $\beta$ (but not $\operatorname{LXR} \alpha$ ) were demonstrated to be resistant to dexamethasone-induced hyperglycaemia, hyperinsulinaemia and hepatic steatosis, but remained sensitive to dexamethasone-dependent immune system repression (Patel et al. 2011). Moreover, as GCs promote muscle wasting and lipolysis, they also increase the bioavailability of substrates for gluconeogenesis (Divertie et al. 1991, Kim et al. 2012; Fig. 1). Finally, fat accumulation leads to hepatic steatosis (Fransson et al. 2013), which, by itself, attenuates insulin sensitivity (Kim et al. 2012). To summarise, elevated GC levels promote gluconeogenesis in hepatic tissue leading to fasting hyperglycaemia. 


\section{Bone tissue}

Osteoporosis is a common side effect observed in patients on GC-based therapy (Hoes et al. 2010). GCs also suppress osteoblast function, including osteocalcin synthesis (Prummel et al. 1991; Fig. 1). Osteocalcin is an osteoblastspecific peptide that is reported to be involved in normal murine fuel metabolism (Ferron et al. 2008). In a pioneering work by Lee et al. (2007), it was demonstrated, both in cell culture and in mice, that osteocalcin increased pancreatic $\beta$-cell proliferation as well as insulin expression and release, resulting in improved glucose tolerance. In addition, uncarboxylated osteocalcin increased adiponectin expression and secretion in adipose tissue, which in turn enhanced insulin sensitivity (Lee et al. 2007). Serum osteocalcin concentrations are positively correlated with improved glucose control (Bao et al. 2011) in the development type 2 diabetes in humans. In another study, osteoblast-targeted disruption of GC signalling significantly attenuated the suppression of osteocalcin synthesis and prevented the development of IR, glucose intolerance and abnormal weight gain in corticosteronetreated mice (Brennan-Speranza et al. 2012). Nearly, identical effects were observed in GC-treated animals following hepatic expression of both carboxylated and uncarboxylated osteocalcin. These data suggest a link between effects of GC on the skeleton and the effects of steroid hormone on glucose homeostasis.

\section{Effects of GC treatment on pancreatic $\beta$-cells and insulin secretion}

Pancreatic $\beta$-cells respond to increasing plasma glucose levels by secreting insulin, which maintains glycaemia within narrow physiological ranges. This key function can be altered by GCs through direct and indirect actions and may also depend on action of GCs as acute or chronic stimuli. In the next sections, we consider the different aspects of GCs' effects on $\beta$-cells.

\section{Acute effects of GCs}

The direct in vitro effects of GCs on glucose-stimulated insulin secretion (GSIS) are generally inhibitory and occur within a few minutes, as demonstrated in isolated rat islets exposed to corticosterone $(0.02-20 \mathrm{mg} / \mathrm{l})$ (Billaudel \& Sutter 1979; Fig. 2A, left). This inhibitory action involves $\alpha$-adrenergic signalling due to the blockage of GCs' effect by phentolamine (a non-selective $\alpha$-adrenergic antagonist; Barseghian \& Levine 1980). This rapid impact of GCs is not reproduced by synthetic steroids. GSIS inhibition in mouse (Lambillotte et al. 1997) and rat islets (Zawalich et al. 2006) is manifested only after the third hour of exposure to $1 \mu \mathrm{M}$ dexamethasone.

GCs may also exert a negative in vivo effect during acute administration. A single oral dose of prednisolone $(75 \mathrm{mg}$; van Raalte et al. 2010) or dexamethasone (1 mg; Schneiter $\&$ Tappy 1998) in healthy volunteers resulted in decreased insulin secretion and/or a reduced insulinogenic index (the ratio between $\Delta$ insulinaemia and $\Delta$ glycaemia) during a meal or an oral glucose tolerance test (oGTT) respectively. In contrast, other studies did not demonstrate this acute GC effect in healthy men (Vila et al. 2010) or normal adult rats (Stojanovska et al. 1990) during an i.v. or oGTT respectively. Similar to the in vitro observations mentioned earlier, increased sympathetic drive may be involved in GCs' inhibition of in vivo insulin secretion (Longano \& Fletcher 1983). This hypothesis is based on a study conducted in adult Swiss mice treated with hydrocortisone (300 mg/kg body weight) $1 \mathrm{~h}$ before determining fed blood glucose and plasma insulin values. The insulinogenic index was reduced $1 \mathrm{~h}$ after steroid administration in fed, mice but unaltered when chlorisondamine (a ganglionic blocker) or phentolamine was given $10 \mathrm{~min}$ before GC administration (Longano \& Fletcher 1983; Fig. 2B, left). Overall, acute exposure or administration of GCs appears to cause a decline in the insulinogenic index in humans and rodents, and this effect may be mediated by sympathetic activation of $\alpha$-adrenergic receptors. It is important to highlight that $24 \mathrm{~h}$ after interrupting GC administration, all $\beta$-cell function parameters return to normal values (van Raalte et al. 2010).

\section{Chronic effects of GCs}

As observed in acute in vitro experiments, chronic incubation (hours to days) with synthetic GCs in in vitro conditions leads to decreased GSIS in rodent isolated islets, dispersed $\beta$-cells and insulin-secreting cell lines (Lambillotte et al. 1997, Shao et al. 2004, Ullrich et al. 2005, Zawalich et al. 2006). GCs' deleterious effects on GSIS involve impaired glucose oxidative metabolism (Shao et al. 2004), activation of repolarising $\mathrm{K}^{+}$channels (Ullrich et al. 2005), generation of reactive oxygen species (Roma et al. 2011), endoplasmic reticulum dyshomeostasis (Linssen et al. 2011), activation of 11ß-HSD1 (Davani et al. 2000) and decreased efficiency of intracellular $\mathrm{Ca}^{2+}$ on the secretory response (Lambillotte et al. 1997, Shao et al. 2004, Zawalich et al. 2006; Fig. 2A, right).

However, in contrast to the above-mentioned inhibitory effects observed in both acute and long-term GC

Published by Bioscientifica Ltd 
A

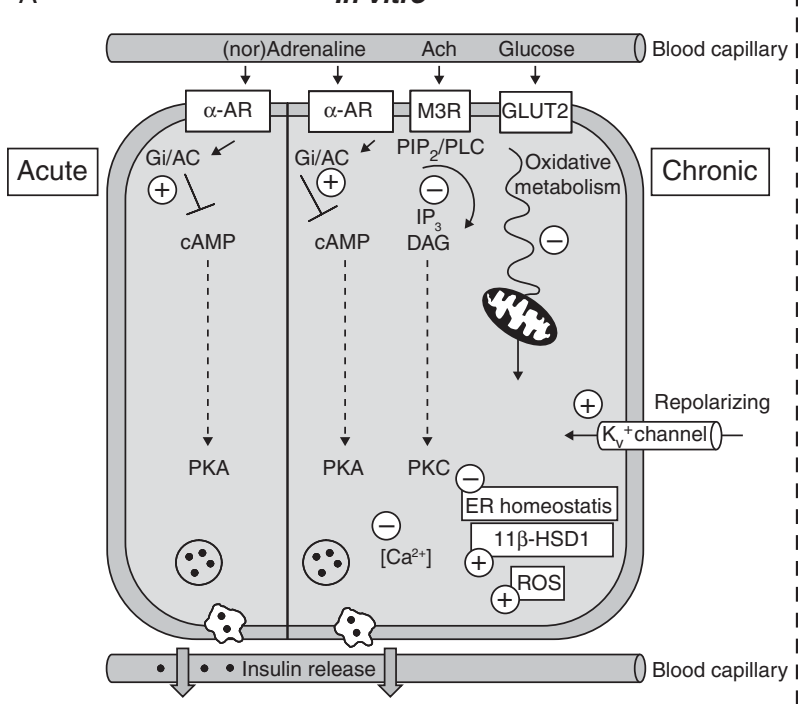

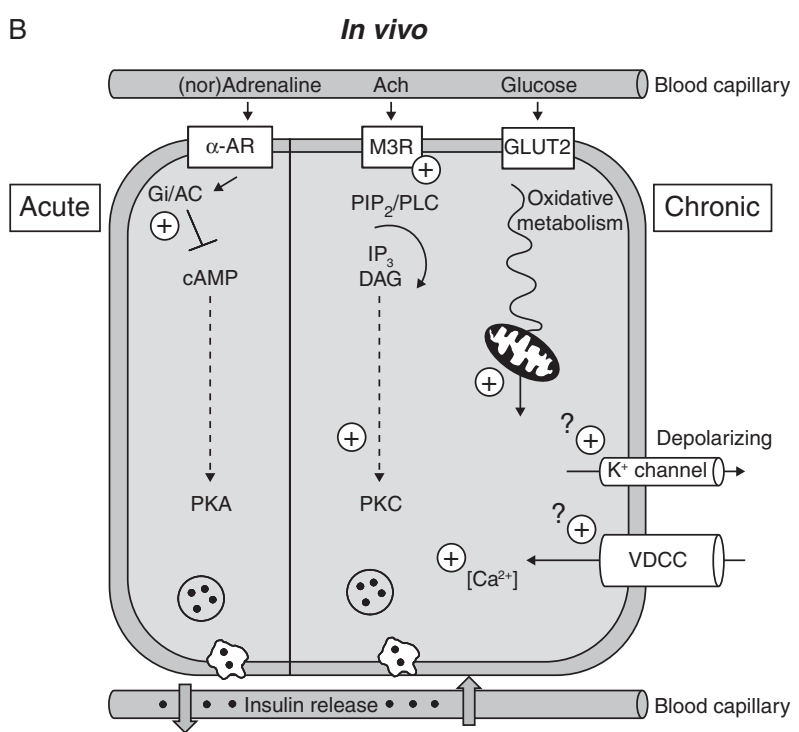

\section{Figure 2}

Sites of the insulin secretory process affected by in vitro or in vivo (ex vivo) exposure to glucocorticoids (GCs). In (A), the known components involved in the acute or chronic in vitro effects of GCs on the $\beta$-cell insulin secretory process are highlighted with a positive signal (indicates GCs stimulate/ increase that action/function) or a negative signal (indicates GCs inhibit/diminish that action/function). Most notably, GCs impair $\beta$-cell glucose metabolism, favour repolarising $\mathrm{K}_{\mathrm{v}}{ }^{+}$currents, decrease PKA and PKC activation, induce ER dyshomeostasis, increase $11 \beta$-HSD1 activity and ROS generation and impair calcium handling. Together, these effects inhibit insulin secretion. In (B), the known components involved in $\beta$-cell function, which are affected by acute or long-term in vivo GC treatment, are highlighted with a positive signal, which indicates increased content or

incubation, chronic in vivo administration of these steroids leads to up-regulation of $\beta$-cell function as a result of the compensatory adaptation to GC-induced IR. Administration of high doses of prednisolone $(30 \mathrm{mg})$ or dexamethasone (2-15 $\mathrm{mg}$ ) to healthy individuals for prolonged periods (up to 15 days and up to 4 days respectively) resulted in normoglycaemia or a modest increase in fasting glycaemia (Beard et al. 1984, Schneiter \& Tappy 1998, Hollindgal et al. 2002, Willi et al. 2002, Nicod et al. 2003, Ahrén 2008, van Raalte et al. 2010, Petersons et al. 2013). Importantly, in most of these studies, volunteers developed hyperinsulinaemia. In fact, during glucose challenging with a hyperglycaemic-clamp (Beard et al. 1984, Nicod et al. 2003) or an oGTT (Schneiter \& Tappy 1998, Hollindgal et al. 2002, Willi et al. 2002), insulin release was significantly higher in GC-treated individuals compared with control groups. The plasma C-peptide values were also elevated after treatment with activity. Most notably, augmented glucose metabolism and cholinergic pathway activity cause increased calcium influx and insulin secretion. In this context, a positive GC effect on $\mathrm{K}^{+}$and VDCC could not be excluded. $A C$, adenylyl cyclase; Ach, acetylcholine; $\alpha A R, \alpha$ adrenergic receptor; DAG, diacylglycerol; ER, endoplasmic reticulum; Gi, G-coupled inhibitory protein; GLUT2, glucose transporter 2; $I_{P_{3}}$, inositol triphosphate; $\mathrm{K}^{+}$, ATP- dependent $\mathrm{K}^{+}$channel; $\mathrm{K}_{\mathrm{v}}{ }^{+}$, voltage-dependent $\mathrm{K}^{+}$channel; M3R, muscarinic receptor type 3; $\mathrm{PIP}_{2}$, phosphatidylinositol bisphosphate; PKA, protein kinase $A$; PLC, phospholipase C; ROS, reactive oxygen species; VDCC, voltage-dependent $\mathrm{Ca}^{2+}$ channel; 11 $\beta$-HSD1, $11 \beta$-hydroxysteroid dehydrogenase type 1 .

prednisolone in healthy men at basal conditions (Hollindgal et al. 2002) and during a meal tolerance test (van Raalte et al. 2010). This enhanced $\beta$-cell function was also observed in adult rats treated for up to 13 consecutive days with dexamethasone $(0.125-2.0 \mathrm{mg} / \mathrm{kg})$ based on basal hyperinsulinaemia (Novelli et al. 1999, Karlsson et al . 2001, Rafacho et al. 2008) or in vivo glucose challenging (Rafacho et al. 2008, 2011). This augmented $\beta$-cell function occurred in a dose- (Rafacho et al. 2008) and time-dependent manner (Rafacho et al. 2011). In normal adult mice, administration of dexamethasone for 10 days or corticosterone from the 1st consecutive week also resulted in basal hyperinsulinaemia (Thomas et al. 1998, Fransson et al. 2013).

This hyperinsulinaemia is consistent with insulin hypersecretion observed in pancreatic islets isolated from GC-treated rats (Novelli et al. 1999, Karlsson et al. 2001, Rafacho et al. 2008, 2010a,b). This enhanced $\beta$-cell

Published by Bioscientifica Ltd. 
secretion involves an improvement in glucose responsiveness (Karlsson et al. 2001, Rafacho et al. 2008), sensitivity (Rafacho et al. 2008) and oxidative metabolism (Rafacho et al. 2010a) as well as augmented $\mathrm{Ca}^{2+}$ handling (Rafacho et al. 2010a) and an improved response to cholinergic signals (Angelini et al. 2010, Rafacho et al. 2010a, b; Fig. 2B, right). The islet compensatory response is also accompanied by structural changes. It has been demonstrated that, $\beta$-cell mass increases in a time- (Rafacho et al. 2011) and dose-dependent manner (Rafacho et al. 2009) with GC administration, according to the correspondent degree of insulin insensitivity. Taken together, these results show that when humans or animal models are exposed to prolonged steroid treatment, they develop augmented $\beta$-cell function and mass to counteract the IR resulting from GC administration.

\section{GC treatment, $\beta$-cell dysfunction and glucose intolerance}

Depending on the GC regimen, glucose homeostasis is maintained at normal or near normal physiological conditions by adaptive $\beta$-cell compensations. However, these adaptations do not always guarantee an adequate glucose homeostasis. Although insulin hypersecretion observed after prolonged steroid treatment appears to be consistent in most experiments carried out in healthy volunteers (Beard et al. 1984, Schneiter \& Tappy 1998, Ahrén 2008, van Raalte et al. 2010) and normal adult rats (Karlsson et al. 2001, Rafacho et al. 2008, 2009, 2011), glucose intolerance is also present. In these studies, hyperinsulinaemia is normally associated with normoglycaemia or modest increases in blood glucose values, but the insulin (Schneiter \& Tappy 1998, Rafacho et al. 2008, 2011) and C-peptide hypersecretion (van Raalte et al. 2010) during glucose or meal challenges, respectively, do not prevent elevation in postprandial blood glucose levels. Therefore, the insulinogenic index may not necessarily match the peripheral insulin demand imposed by GCs.

The negative impact of GCs on glucose homeostasis is more apparent in individuals or rodents with any degree of susceptibility to glucose intolerance, such as those with low insulin sensitivity (Larsson \& Ahrén 1999), low insulin response to glucose (Wajngot et al. 1992), first-degree relatives of patients with type 2 diabetes (Jensen et al. 2012), obesity (Besse et al. 2005) and those who are older (Novelli et al. 1999). In these contexts, $\beta$-cell function does not correspond to the peripheral insulin demand, and the deregulation of glucose homeostasis becomes more pronounced, reinforcing that individual background is a critical factor. Indeed, this susceptibility to $\beta$-cell failure after treatment with dexamethasone has also been observed in animal models with an obesity background, such as fa/fa rats (Ogawa et al. 1992) and ob/ob mice (Khan et al. 1992).

In an attempt to analyse whether GCs have any direct effects on $\beta$-cells in vivo independent of peripheral GC actions, a transgenic mice model that specifically overexpresses GR in these cells was generated (Delaunay et al. 1997, Davani et al. 2004). These mice were normoglycaemic, but displayed glucose intolerance associated with reduced insulin secretion during a glucose load (Delaunay et al. 1997). When these transgenic mice aged, hyperglycaemia developed together with marked glucose intolerance and reduced in vivo and ex vivo GSIS. Remarkably, no change in $\beta$-cell apoptosis was observed in these mice (Davani et al. 2004). This deterioration in GSIS was prevented by incubating islets with benextramine (a selective $\alpha 2$-adrenergic receptor antagonist), suggesting the involvement of adrenergic signals. In any case, the analysis of direct GC effects on $\beta$-cells in vivo is difficult because the systemic metabolic consequences of GC treatment most likely mask the GC-mediated changes in $\beta$-cell function. Of note, almost all the morphofunctional $\beta$-cell changes elicited by GC administration are transitory and reversible after 10 days of discontinuation of steroid treatment in rats, suggesting an unacknowledged plasticity in the regulation of $\beta$-cell function and growth (Rafacho et al. 2010b).

\section{Effects of GCs on glucagon release and other islet hormones}

Glucagon secretion by pancreatic $\alpha$-cells plays a key role in glucose homeostasis. Glucagon's release is enhanced at low plasma glucose levels, but decreases under hyperglycaemic conditions (Quesada et al. 2008, Marroqui et al. 2014). Glucagon is one of the most important hyperglycaemic hormones and acts as insulin's counterpart, opposing numerous anabolic insulin-mediated actions. The hyperglycaemic effect is mainly produced by activating hepatic glycogenolysis and gluconeogenesis, which results in the release of endogenous glucose into the bloodstream. This process restores normoglycaemia under hypoglycaemic conditions (Quesada et al. 2008, Marroqui et al. 2014). Hyperglucagonaemia may be present in diabetes. In addition, inhibition of glucagon release at high glucose levels may be impaired in this metabolic condition. This impaired $\alpha$-cell function can lead to higher hepatic glucose output, further contributing to hyperglycaemia in diabetic patients (Quesada et al. 2008; Marroqui et al. 2014). As in

Published by Bioscientifica Ltd. 
the case of $\beta$-cells, in the next section we summarise the acute and chronic effects of GCs on $\alpha$-cell function.

\section{Acute effects of GCs on $\alpha$-cell function and glucagon release}

One study reported that corticosterone $\left(10^{-7} \mathrm{M}\right)$ potentiated glucagon release induced by a glucose-free medium or arginine in isolated perfused rat pancreas (Barseghian \& Levine 1980). In contrast, incubation of mouse pancreatic islets with dexamethasone $(0.5-50 \mathrm{nM})$, corticosterone $(50 \mathrm{nM})$ or 11-dehydrocorticosterone $(50 \mathrm{nM})$ for $2 \mathrm{~h}$ reduced glucagon secretion induced by low glucose levels, effects that were reversed by a GR antagonist (Swali et al. 2008). The inhibitory action of 11-dehydrocorticosterone was partially reversed by a selective 11 $\beta$-HSD1 inhibitor. This fact, along with the co-localisation of this enzyme in human and rodent islet $\alpha$-cells, indicates that this islet cell type serves an important local function in pancreatic GC metabolism (Swali et al. 2008). This situation may be different in other species, for example in rats, where this enzyme is expressed in non- $\alpha$-cells (Rafacho et al. 2014). In contrast with the above-mentioned results, prednisolone $\left(10^{-5} \mathrm{M}\right)$ failed to modify glucagon secretion in mouse pancreatic islets (Marco et al. 1976). Likewise, incubation of rat pancreatic islets with dexamethasone $(1 \mu \mathrm{M})$ for $3 \mathrm{~h}$ did not modify glucagon secretion (Rafacho et al. 2014). Thus, in vitro experiments with acute GC exposure have reported divergent effects on glucagon secretion. These divergences may depend on different factors, including the preparation and species studied as well as the specificity and potency of the different GCs used.

\section{Chronic effects of GCs on $\alpha$-cell function and glucagon release}

$\alpha$-cell growth regulation by long-term GC exposure has been explored during development. $\alpha$-cell mass was decreased in 21-day-old foetuses obtained from pregnant rats that received dexamethasone in drinking water $(1 \mu \mathrm{g} / \mathrm{ml})$ either during the last week of pregnancy or throughout gestation (Dumortier et al. 2011). In contrast, GR inactivation in the pancreatic $\beta$-cell (rat insulin promoter-Cre transgene) or in cells expressing pancreatic and duodenal homeobox 1 , which is involved in pancreas development, did not modify $\alpha$-cell mass in adult mice (Gesina et al. 2004). Adult rats treated with dexamethasone $(1 \mathrm{mg} / \mathrm{kg})$ for 5 consecutive days exhibited a $50 \%$ increase in $\alpha$-cell mass (Rafacho et al. 2014). Similarly, administration of corticosterone to adult rats fed a high-fat diet promoted a synergistic positive effect on $\alpha$-cell mass (Beaudry et al. 2013). In general, GC administration in adults appears to up-regulate $\alpha$-cell mass, while the opposite effect is observed during development.

Glucagon release is also modulated by GCs. Rats treated with dexamethasone $(1 \mathrm{mg} / \mathrm{kg})$ for 5 consecutive days exhibited hyperglucagonaemia (Rafacho et al. 2014). In this model, isolated pancreatic islets exhibited impaired inhibition of glucagon release at high glucose levels. Similarly, dexamethasone $(0.25 \mathrm{mg} / \mathrm{kg})$ administered for 7 days in rhesus macaques induced fasting hyperglucagonaemia (Cummings et al. 2013), and prednisolone (0.2-0.3 mg daily) administered for 4 days increased basal and arginine-induced glucagon secretion in isolated mouse islets (Marco et al. 1976). In contrast to the abovementioned results obtained for in vivo GC treatment, glucagon release was suppressed in isolated rat islet cells incubated for $18 \mathrm{~h}$ with dexamethasone at $10^{-9}$ and $10^{-10} \mathrm{M}$, but was without effect at higher steroid concentrations (Papachristou et al. 1994). Thus, in vivo and ex vivo chronic studies mostly point to enhanced $\alpha$-cell secretion after GC administration. The resulting hyperglucagonaemia may aggravate GC-induced hyperglycaemia by stimulating hepatic glucose release and opposing insulin actions (Quesada et al. 2008; Fig. 3).

Clinical studies have also evaluated GCs' effects on human $\alpha$-cell function. Administration of prednisolone (40-100 mg daily) for up to 4 days induced fasting hyperglucagonaemia and glucagon hypersecretion in response to arginine (Marco et al. 1973). Similarly, daily dexamethasone treatment $(2 \mathrm{mg})$ for 3 days led to increased basal plasma glucagon levels and enhanced alanine-induced glucagon release in non-obese subjects (Wise et al. 1973). Both responses were even more pronounced in obese individuals and patients with Cushing's syndrome. Moreover, administration of dexamethasone ( $3 \mathrm{mg}$ twice daily for 2 days) and prednisolone (30 $\mathrm{mg}$ for 2 consecutive weeks) led to increased fasting and postprandial glucagon levels (Beard et al. 1984, van raalte et al. 2013). In contrast, in a few studies, fasting glucagon concentrations were found to be unchanged by dexamethasone ( $3 \mathrm{mg}$ twice daily for 2 and $1 / 2$ days; Larsson \& Ahrén 1999). Thus, the majority of clinical studies show that GC treatment may up-regulate $\alpha$-cell function, which may enhance GCs' diabetogenic actions (Fig. 3).

\section{Effects of GCs on somatostatin, amylin and ghrelin release}

Pancreatic $\delta$-cells secrete somatostatin, which indirectly affects glucose homeostasis, suppressing both insulin and

Published by Bioscientifica Ltd 


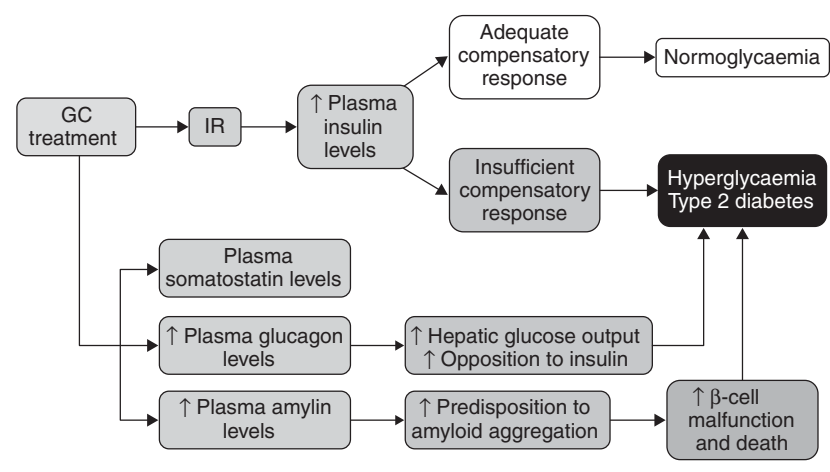

Figure 3

Diabetogenic effects of GC treatment: implication of islet hormones. GC treatment can induce IR in peripheral tissues. As a compensatory adaptive process, the endocrine pancreas increases insulin release, leading to hyperinsulinaemia. An adequate compensatory response to the insulin requirements imposed by IR allows for normoglycaemia. However, an insufficient $\beta$-cell response could lead to impaired glucose tolerance, which can progress to overt hyperglycaemia and type 2 diabetes. GC treatment also induces high plasma levels of glucagon and amylin, and may affect somatostatin concentrations. Although somatostatin inhibits $\alpha$ - and $\beta$-cells, the potential changes in this hormone induced by GCs do not appear to produce a significant negative effect in these conditions. Hyperglucagonaemia increases hepatic glucose output, which exacerbates hyperglycaemia and glucose intolerance and further opposes insulin action, decreasing the insulin effect. High amylin levels have been related with increased predisposition to amyloid formation in decreased insulin sensitivity conditions, such as those generated by GCs. Amyloid aggregation is related with increased $\beta$-cell death and malfunction. The molecular mechanisms underlying the high plasma levels of glucagon and amylin induced by GC treatment are still unknown.

glucagon release (Quesada et al. 2008). In vivo experiments showed that dexamethasone administration $(0.5 \mathrm{mg} / \mathrm{kg})$ for 3 or 8 days in rats increased somatostatin gene expression and protein content in the pancreas (Papachristou et al. 1994). However, plasma somatostatin levels were not measured in these conditions. In in vitro experiments, incubation of isolated islet-cells with dexamethasone for $18 \mathrm{~h}$ produced a biphasic effect: while low doses $\left(10^{-10} \mathrm{M}\right)$ stimulated the somatostatin gene and protein expression, high doses $\left(10^{-8}-10^{-5} \mathrm{M}\right)$ produced the opposite effect (Papachristou et al. 1994). At this chronic exposure, the high doses reduced somatostatin release into the medium. When foetal pancreatic islets were cultured for 8 days with corticosterone $(0.1 \mu \mathrm{g} / \mathrm{ml})$, both the somatostatin concentration in the medium and the islet somatostatin content were increased (McEvoy et al. 1981). Thus, few experiments indicate that GC may regulate directly or indirectly $\delta$-cell function (Fig. 3). Elevation in plasma somatostatin concentrations should inhibit $\alpha$ and $\beta$-cell functions under normal physiological conditions. However, this appears not to be the case during GC administration, given that GC treatment results in hyperglucagonaemia and hyperinsulinaemia.

The islet amyloid polypeptide (IAPP), also called amylin, is co-secreted with insulin by pancreatic $\beta$-cells in response to food intake, most likely via the same mechanisms that allow for insulin release. This hormone decreases postprandial glycaemia by inhibiting gastric emptying and suppressing glucagon secretion (Westermark et al. 2011). However, type 2 diabetes has also been related with the formation of toxic amyloid aggregates that can induce $\beta$-cell apoptosis (Westermark et al. 2011). This aggregation might be associated with IR and insulin (and amylin) hypersecretion (Westermark et al. 2011), which also result from GC treatment. With this enhanced hormonal release, impaired intracellular IAPP processing may initiate the process of amylin aggregation. For instance, dexamethasone treatment for up to 12 days led to increased levels of both proinsulin and Iapp mRNA in rat islets (Bretherton-Watt et al. 1989, Koranyi et al. 1992). Similarly, both enhanced plasma amylin levels and amylin secretion from isolated pancreata were found in dexamethasone-induced IR rats (Pieber et al. 1993, Mulder et al. 1995). Similar findings in amylin changes have been reported in humans after dexamethasone treatment (Ludvik et al. 1993), indicating that GC administration may enhance IAPP release (Fig. 3).

Ghrelin is released not only by P/D1 cells from the stomach but also by $\varepsilon$-cells from the pancreas (Wierup et al. 2013). Only few $\varepsilon$-cells are present in each islet. Ghrelin inhibits insulin and somatostatin secretion, but increases glucagon release (Chuang et al. 2011, Wierup et al. 2013). In addition, this hormone potently stimulates growth hormone release from the anterior pituitary gland and stimulates appetite (Malik et al. 2008). In hypercortisolemic patients with Cushing's disease, plasma ghrelin concentrations increased after successful surgery, while prednisolone administration $(30 \mathrm{mg} /$ day) for 5 days decreased plasma ghrelin levels in healthy individuals (Otto et al. 2004). However, no changes were observed in response to a unique bolus of hydrocortisone $(0.6 \mathrm{mg} / \mathrm{kg})$ in healthy men (Vila et al. 2010). In a neonatal rat model, dexamethasone $(0.5-0.05 \mathrm{mg} / \mathrm{kg})$ administrated for 4 consecutive days led to augmented plasma ghrelin levels in newborns (Bruder et al. 2005). However, any of the above-mentioned studies discriminated the ghrelin source, either the stomach or the pancreas. Thus, much research is necessary to address whether GCs can affect the function of $\varepsilon$ islet-cells.

Published by Bioscientifica Ltd 


\section{Conclusions and future perspectives}

The diabetogenic effects of GCs are a limiting factor to their clinical use, particularly in individuals with diabetes risk factors. These side effects include unfavourable actions on peripheral tissues, such as skeletal muscle, liver, bone and adipose tissue, which mainly result, among other effects, in decreased insulin sensitivity, augmenting insulin needs. In response to this GC-induced IR, the endocrine pancreas undergoes compensatory $\beta$-cell changes in function and mass, which lead to hyperinsulinaemia and enhanced stimulated insulin release, to maintain normoglycaemia. Despite the fact that most of these adaptations are observed in healthy subjects and animal models under GC treatment, the adaptations do not necessarily guarantee an adequate insulinogenic index to prevent glucose intolerance. These $\beta$-cell adaptations are less efficient in susceptible individuals, increasing the risk of impaired glucose homeostasis during GC treatment. Up-regulated $\beta$-cell function resulting from steroid treatment contrasts with the direct inhibitory actions observed in both acute and long-term in vitro GC exposures. Thus, the effects derived from in vivo GC treatment may prevail over the potential direct GC actions on $\beta$-cells. In any case, further research is necessary to unravel the molecular mechanisms of both direct and indirect GC actions on the endocrine pancreas.

Several studies have also documented acute and chronic GC effects on non- $\beta$ pancreatic cells. The mechanisms implicated are not clear, but may involve multiple factors, including direct actions on islet cells as well as effects derived from adaptations to IR, hyperglycaemia, hyperinsulinaemia or other conditions. Remarkably, the majority of in vivo animal studies and clinical reports show that, in addition to hyperinsulinaemia, GC treatment induces higher plasma levels of glucagon and amylin and may probably affect somatostatin. The increased plasma amylin levels might also be considered diabetogenic because enhanced IAPP concentrations may lead to increased rates of toxic amylin aggregation (Couce et al. 1996). In addition, the hyperglucagonaemia observed with GC treatment opposes insulin actions and may aggravate steroid-induced hyperglycaemia by increasing hepatic glucose output, as indicated in diabetes (Quesada et al. 2008). Thus, the impaired release of the different islet hormones may increase the diabetogenic effects of GCs.

The majority of studies about GC actions involve the use of murine models, and thus, prudence is required when translating this experimental data to humans. However, it is also important to mention that the prolonged duration of several GC therapies in clinical practice may exceed the safe period proposed in experimental approaches in human studies, which generally do not surpass $2-15$ days of GC treatment (van Raalte et al. 2009). Thus, experimental data from human, although of great relevance, fail to totally mimic the conditions of clinical practice (i.e. duration). Elaboration of protocols to investigate GC actions in human volunteers is not feasible, considering the risk of irreversible negative effects, ethical issues, as well as the nature of ex vivo and in vitro techniques available for the mechanistic studies (van Raalte et al. 2009). In this regard, animal models are valuable tools, because part of the above-mentioned limitations can be resolved.

Improved knowledge of GCs' intracellular signalling mechanisms and effects will help to design better GC therapies. In this regard, it has been suggested that gene transrepression accounts for the majority of therapeutic GC effects, while transactivation of metabolic target genes is mainly responsible for the side effects (Strehl \& Buttgereit 2013). Using this concept, several GR agonists dissociating transrepression from transactivation were developed (Löwenberg et al. 2008). Some of these agonists have proven useful for maintaining GCs' anti-inflammatory and immunosuppressive effects, while reducing side effects such as hyperglycaemia. However, the above-mentioned concept may be over-simplistic, and side effects may not only be explained by transactivation but also by nongenomic actions (Vandevyver et al. 2013). Thus, a great deal of research is still necessary to develop GR agonists with reduced drawbacks for glucose homeostasis. Moreover, the combination of GC-based therapies with glucose-lowering drugs could also be an interesting alternative explored to minimise the disadvantages of GC treatment.

\section{Declaration of interest}

The authors declare that there is no conflict of interest that could be perceived as prejudicing the impartiality of the research reported.

\section{Funding}

This study was supported by grants from the Brazilian foundation Conselho Nacional de Desenvolvimento Científico e Tecnológico (CNPq 471397/2011-3), the Spanish foundations Ministerio de Ciencia e Innovación (BFU201342789; BFU2011-28358) and the European Foundation for the Study of Diabetes (EFSD/BI Basic Programme and the Albert Renold Fellowship). CIBERDEM is an initiative of the Instituto de Salud Carlos III.

\section{Author contribution statement}

A R, H O, A N and I Q discussed and wrote the manuscript. All authors approved the final version of the manuscript to be published.

Published by Bioscientifica Ltd. 


\section{Acknowledgements}

The authors give special thanks to the members of their laboratories.

\section{References}

Ahrén B 2008 Evidence that autonomic mechanisms contribute to the adaptive increase in insulin secretion during dexamethasone-induced insulin resistance in humans. Diabetologia 51 1018-1024. (doi:10.1007/ s00125-008-0995-y)

Anagnostis P, Athyros VG, Tziomalos K, Karagiannis A \& Mikhailidis DP 2009 Clinical review: The pathogenetic role of cortisol in the metabolic syndrome: a hypothesis. Journal of Clinical Endocrinology 94 2692-2701. (doi:10.1210/jc.2009-0370)

Andrews RC \& Walker BR 1999 Glucocorticoids and insulin resistance: old hormones, new targets. Clinical Science 96 513-523. (doi:10.1042/ CS19980388)

Angelini N, Rafacho A, Boschero AC \& Bosqueiro JR 2010 Involvement of the cholinergic pathway in glucocorticoid-induced hyperinsulinemia in rats. Diabetes Research and Clinical Practice 87 184-191. (doi:10.1016/ j.diabres.2009.11.008)

Bao YQ, Zhou M, Zhou J, Lu W, Gao YC, Pan XP, Tang JL, Lu HJ \& Jia WP 2011 Relationship between serum osteocalcin and glycaemic variability in type 2 diabetes. Clinical and Experimental Pharmacology \& Physiology 38 50-54. (doi:10.1111/j.1440-1681.2010.05463.x)

Barseghian G \& Levine R 1980 Effect of corticosterone on insulin and glucagon secretion by the isolated perfused rat pancreas. Endocrinology 106 547-552. (doi:10.1210/endo-106-2-547)

Beard JC, Halter JB, Best JD, Pfeifer MA \& Porte D Jr 1984 Dexamethasoneinduced insulin resistance enhances $\mathrm{B}$ cell responsiveness to glucose level in normal men. American Journal of Physiology 247 E592-E596.

Beaudry JL, D'souza AM, Teich T, Tsushima R \& Riddell MC 2013 Exogenous glucocorticoids and a high-fat diet cause severe hyperglycemia and hyperinsulinemia and limit islet glucose responsiveness in young male Sprague-Dawley rats. Endocrinology 154 3197-3208. (doi:10.1210/en.2012-2114)

Besse C, Nicod N \& Tappy L 2005 Changes in insulin secretion and glucose metabolism induced by dexamethasone in lean and obese females. Obesity Research 13 306-311. (doi:10.1038/oby.2005.41)

Billaudel B \& Sutter BC 1979 Direct effect of corticosterone upon insulin secretion studied by three different techniques. Hormone and Metabolic Research 11 555-560. (doi:10.1055/s-0028-1092779)

Brennan-Speranza TC, Henneicke H, Gasparini SJ, Blankenstein KI, Heinevetter U, Cogger VC, Svistounov D, Zhang Y, Cooney GJ, Buttgereit F et al. 2012 Osteoblasts mediate the adverse effects of glucocorticoids on fuel metabolism. Journal of Clinical Investigation 122 4172-4189. (doi:10.1172/JCI63377)

Bretherton-Watt D, Ghatei MA, Bloom SR, Jamal H, Ferrier GJ, Girgis SI \& Legon S 1989 Altered islet amyloid polypeptide (amylin) gene expression in rat models of diabetes. Diabetologia 32 881-883. (doi:10.1007/BF00297454)

Brown RW, Chapman KE, Edwards CR \& Seckl JR 1993 Human placental $11 \beta$-hydroxysteroid dehydrogenase: evidence for and partial purification of a distinct NAD-dependent isoform. Endocrinology 132 2614-2621.

Bruder ED, Jacobson L \& Raff H 2005 Plasma leptin and ghrelin in the neonatal rat: interaction of dexamethasone and hypoxia. Journal of Endocrinology 185 477-484. (doi:10.1677/joe.1.06159)

Caro JF \& Amatruda JM 1982 Glucocorticoid-induced insulin resistance: the importance of postbinding events in the regulation of insulin binding, action, and degradation in freshly isolated and primary cultures of rat hepatocytes. Journal of Clinical Investigation 69 866-875. (doi:10.1172/JCI110526)

Cassuto H, Kochan K, Chakravarty K, Cohen H, Blum B, Olswang Y, Hakimi P, $\mathrm{Xu}$ C, Massillon D, Hanson RW et al. 2005 Glucocorticoids regulate transcription of the gene for phosphoenolpyruvate carboxykinase in the liver via an extended glucocorticoid regulatory unit. Journal of Biological Chemistry 280 33873-33884. (doi:10.1074/jbc. M504119200)

Chen DY, Bambah-Mukku D \& Pollonini G 2012 Glucocorticoid receptors recruit the CaMKII $\alpha$-BDNF--CREB pathways to mediate memory consolidation. Nature Neuroscience 15 1707-1714. (doi:10.1038/nn. 3266)

Christ-Crain M, Kola B, Lolli F, Fekete C, Seboek D, Wittmann G, Feltrin D, Igreja SC, Ajodha S, Harvey-White J et al. 2008 AMP-activated protein kinase mediates glucocorticoid-induced metabolic changes: a novel mechanism in Cushing's syndrome. FASEB Journal 22 1672-1683. (doi:10.1096/fj.07-094144)

Chuang JC, Sakata I, Kohno D, Perello M, Osborne-Lawrence S, Repa JJ \& Zigman JM 2011 Ghrelin directly stimulates glucagon secretion from pancreatic $\alpha$-cells. Molecular Endocrinology 25 1600-1611. (doi:10.1210/ me.2011-1001)

Couce M, Kane LA, O'Brien TD, Charlesworth J, Soeller W, McNeish J, Kreutter D, Roche P \& Butler PC 1996 Treatment with growth hormone and dexamethasone in mice transgenic for human islet amyloid polypeptide causes islet amyloidosis and $\beta$-cell dysfunction. Diabetes $\mathbf{4 5}$ 1094-1101. (doi:10.2337/diab.45.8.1094)

Cummings BP, Bremer AA, Kieffer TJ, D'Alessio D \& Havel PJ 2013 Investigation of the mechanisms contributing to the compensatory increase in insulin secretion during dexamethasone-induced insulin resistance in rhesus macaques. Journal of Endocrinology 216 207-215. (doi:10.1530/JOE-12-0459)

Davani B, Khan A, Hult M, Mårtensson E, Okret S, Efendic S, Jörnvall H \& Oppermann UC 2000 Type $111 \beta$-hydroxysteroid dehydrogenase mediates glucocorticoid activation and insulin release in pancreatic islets. Journal of Biological Chemistry 275 34841-34844. (doi:10.1074/ jbc.C000600200)

Davani B, Portwood N, Bryzgalova G, Reimer MK, Heiden T, Ostenson CG, Okret S, Ahren B, Efendic S \& Khan A 2004 Aged transgenic mice with increased glucocorticoid sensitivity in pancreatic $\beta$-cells develop diabetes. Diabetes 53(Suppl 1) S51-S59. (doi:10.2337/diabetes. 53.2007.S51)

Delaunay F, Khan A, Cintra A, Davani B, Ling ZC, Andersson A, Ostenson CG, Gustafsson J, Efendic S \& Okret S 1997 Pancreatic $\beta$ cells are important targets for the diabetogenic effects of glucocorticoids. Journal of Clinical Investigation 100 2094-2098. (doi:10.1172/ JCI119743)

Dimitriadis G, Leighton B, Parry-Billings M, Sasson S, Young M, Krause U, Bevan S, Piva T, Wegener G \& Newsholme EA 1997 Effects of glucocorticoid excess on the sensitivity of glucose transport and metabolism to insulin in rat skeletal muscle. Biochemical Journal $\mathbf{3 2 1}$ 707-712.

Divertie GD, Jensen MD \& Miles JM 1991 Stimulation of lipolysis in humans by physiological hypercortisolemia. Diabetes $401228-1232$. (doi:10.2337/diab.40.10.1228)

Dumortier O, Theys N, Ahn MT, Remacle C \& Reusens B 2011 Impairment of rat fetal $\beta$-cell development by maternal exposure to dexamethasone during different time-windows. PLOS ONE 6 e25576. (doi:10.1371/ journal.pone.0025576)

Engblom D, Kornfeld JW, Schwake L, Tronche F, Reimann A, Beug H, Hennighausen L, Moriggl R \& Schütz G 2007 Direct glucocorticoid receptor-Stat5 interaction in hepatocytes controls body size and maturation-related gene expression. Genes \& Development 21 1157-1162. (doi:10.1101/gad.426007)

Ferron M, Hinoi E, Karsenty G \& Ducy P 2008 Osteocalcin differentially regulates $\beta$ cell and adipocyte gene expression and affects the development of metabolic diseases in wild-type mice. PNAS 105 5266-5270. (doi:10.1073/pnas.0711119105)

Fransson L, Franzén S, Rosengren V, Wolbert P, Sjöholm Å \& Ortsäter H $2013 \beta$-Cell adaptation in a mouse model of glucocorticoid-induced

Published by Bioscientifica Ltd. 
metabolic syndrome. Journal of Endocrinology 219 231-241. (doi:10.1530/JOE-13-0189)

Gesina E, Tronche F, Herrera P, Duchene B, Tales W, Czernichow P \& Breant B 2004 Dissecting the role of glucocorticoids on pancreas development. Diabetes 53 2322-2329. (doi:10.2337/diabetes.53.9.2322)

van der Goes MC, Jacobs JW, Boers M, Andrews T, Blom-Bakkers MA, Buttgereit F, Caeyers N, Cutolo M, Da Silva JA, Guillevin L et al. 2010 Monitoring adverse events of low-dose glucocorticoid therapy: EULAR recommendations for clinical trials and daily practice. Annals of the Rheumatic Diseases 69 1913-1919. (doi:10.1136/ard.2009.124958)

Hoes JN, Jacobs JW, Hulsmans HM, De Nijs RN, Lems WF, Bruyn GA, Geusens PP \& Bijlsma JW 2010 High incidence rate of vertebral fractures during chronic prednisone treatment, in spite of bisphosphonate or alfacalcidol use. Extension of the alendronate or alfacalcidol in glucocorticoid-induced osteoporosis-trial. Clinical and Experimental Rheumatology 28 354-359.

Hollindgal M, Juhl CB, Dall R, Sturis J, Veldhuis JD, Schmitz O \& Pørksen N 2002 Glucocorticoid induced insulin resistance impairs basal but not glucose entrained high-frequency insulin pulsatility in human. Diabetologia 45 49-55. (doi:10.1007/s125-002-8244-y)

Ismaili N \& Garabedian MJ 2004 Modulation of glucocorticoid receptor function via phosphorylation. Annals of the New York Academy of Sciences 1024 86-101. (doi:10.1196/annals.1321.007)

Jensen DH, Aaboe K, Henriksen JE, Vølund A, Holst JJ, Madsbad S \& Krarup T 2012 Steroid-induced insulin resistance and impaired glucose tolerance are both associated with progressive decline of incretin effect in firstdegree relatives of patients with type 2 diabetes. Diabetologia 55 1406-1416. (doi:10.1007/s00125-012-2459-7)

Karlsson S, Ostlund B, Myrsén-Axcrona U, Sundler F \& Ahrén B 2001 B cell adaptation to dexamethasone-induced insulin resistance in rats involves increased glucose responsiveness but not glucose effectiveness. Pancreas 22 148-156. (doi:10.1097/00006676-200103000-00007)

Khan A, Ostenson CG, Berggren PO \& Efendic S 1992 Glucocorticoid increases glucose cycling and inhibits insulin release in pancreatic islets of ob/ob mice. American Journal of Physiology 263 E663-E666.

Kim JS, Lê KA, Mahurkar S, Davis JN \& Goran MI 2012 Influence of elevated liver fat on circulating adipocytokines and insulin resistance in obese Hispanic adolescents. Pediatric Obesity 7 158-164. (doi:10.1111/j. 2047-6310.2011.00014.x)

Kola B, Christ-Crain M, Lolli F, Arnaldi G, Giacchetti G, Boscaro M, Grossman AB \& Korbonits M 2008 Changes in adenosine 5'-monophosphate-activated protein kinase as a mechanism of visceral obesity in Cushing's syndrome. Journal of Clinical Endocrinology 93 4969-4973. (doi:10.1210/jc.2008-1297)

Koranyi L, Bourey R, Turk J, Mueckler M \& Permutt MA 1992 Differential expression of rat pancreatic islet $\beta$-cell glucose transporter (GLUT 2), proinsulin and islet amyloid polypeptide genes after prolonged fasting, insulin-induced hypoglycaemia and dexamethasone treatment. Diabetologia 35 1125-1132. (doi:10.1007/BF00401365)

Lambillotte C, Gilon P \& Henquin JC 1997 Direct glucocorticoid inhibition of insulin secretion. An in vitro study of dexamethasone effects in mouse islets. Journal of Clinical Investigation 99 414-423. (doi:10.1172/ JCI119175)

Lange AJ, Argaud D, el-Maghrabi MR, Pan W, Maitra SR \& Pilkis SJ 1994 Isolation of a cDNA for the catalytic subunit of rat liver glucose-6phosphatase: regulation of gene expression in FAO hepatoma cells by insulin, dexamethasone and cAMP. Biochemical and Biophysical Research Communications 201 302-309. (doi:10.1006/bbrc.1994.1702)

Larsson H \& Ahrén B 1999 Insulin resistant subjects lack islet adaptation to short-term dexamethasone-induced reduction in insulin sensitivity. Diabetologia 42 936-943. (doi:10.1007/s001250051251)

Lee NK, Sowa H, Hinoi E, Ferron M, AhnJD, Confavreux C, Dacquin R, Mee PJ, McKee MD, Jung DY et al. 2007 Endocrine regulation of energy metabolism by the skeleton. Cell 130 456-469. (doi:10.1016/j.cell. 2007.05.047)
Linssen MM, van Raalte DH, Toonen EJ, Alkema W, van der Zon GC, Dokter WH, Diamant M, Guigas B \& Ouwens DM 2011 Prednisoloneinduced $\beta$ cell dysfunction is associated with impaired endoplasmic reticulum homeostasis in INS-1E cells. Cellular Signalling 23 1708-1715. (doi:10.1016/j.cellsig.2011.06.002)

Long F, Wang YX, Liu L, Zhou J, Cui RY \& Jiang CL 2005 Rapid nongenomic inhibitory effects of glucocorticoids on phagocytosis and superoxide anion production by macrophages. Steroids 70 55-61. (doi:10.1016/j. steroids.2004.10.004)

Longano CA \& Fletcher HP 1983 Insulin release after acute hydrocortisone treatement in mice. Metabolism 32 603-608. (doi:10.1016/ 0026-0495(83)90031-8)

Low SC, Chapman KE, Edwards CR \& Seckl JR 1994 'Liver-type' $11 \beta$-hydroxysteroid dehydrogenase cDNA encodes reductase but not dehydrogenase activity in intact mammalian COS-7 cells. Journal of Molecular Endocrinology 13 167-174. (doi:10.1677/jme.0.0130167)

Löwenberg M, Stahn C, Hommes DW \& Buttgereit F 2008 Novel insights into mechanisms of glucocorticoid action and the development of new glucocorticoid receptor ligands. Steroids 73 1025-1029. (doi:10.1016/j. steroids.2007.12.002)

Ludvik B, Clodi M, Kautzky-Willer A, Capek M, Hartter E, Pacini G \& Prager R 1993 Effect of dexamethasone on insulin sensitivity, islet amyloid polypeptide and insulin secretion in humans. Diabetologia 36 84-87. (doi:10.1007/BF00399099)

Malik S, McGlone F, Bedrossian D \& Dagher A 2008 Ghrelin modulates brain activity in areas that control appetitive behavior. Cell Metabolism 7 400-409. (doi:10.1016/j.cmet.2008.03.007)

Mangelsdorf DJ, Thummel C, Beato M, Herrlich P, Schütz G, Umesono K, Blumberg B, Kastner P, Mark M, Chambon P et al. 1995 The nuclear receptor superfamily: the second decade. Cell $\mathbf{8 3} 835-839$. (doi:10.1016/0092-8674(95)90199-X)

Marco J, Calle C, Román D, Díaz-Fierros M, Villanueva ML \& Valverde I 1973 Hyperglucagonism induced by glucocorticoid treatment in man. New England Journal of Medicine 288 128-131. (doi:10.1056/ NEJM197301182880305)

Marco J, Calle C, Hedo JA \& Villanueva ML 1976 Enhanced glucagon secretion by pancreatic islets from prednisolone-treated mice. Diabetologia 12 307-311. (doi:10.1007/BF00420973)

Marroqui L, Alonso-Magdalena P, Merino B, Fuentes E, Nadal A \& Quesada I 2014 Nutrient regulation of glucagon secretion: involvement in metabolism and diabetes. Endocrinology 27 48-62. (doi:10.1017/ S0954422414000031)

McEvoy RC, Leung PE \& Goggins JA 1981 Tissue culture of fetal rat islets: corticosterone promotes D cell maintenance and function. Endocrinology 108 2277-2282. (doi:10.1210/endo-108-6-2277)

Morgan SA, Sherlock M, Gathercole LL, Lavery GG, Lenaghan C, Bujalska IJ, Laber D, Yu A, Convey G, Mayers R et al. 2009 11ß-hydroxysteroid dehydrogenase type 1 regulates glucocortcioid-induced insulin resistance in skeletal muscle. Diabetes 58 2506-2515. (doi:10.2337/db09-0525)

Mulder H, Ahrén B, Stridsberg M \& Sundler F 1995 Non-parallelism of islet amyloid polypeptide (amylin) and insulin gene expression in rats islets following dexamethasone treatment. Diabetologia 38 395-402. (doi:10.1007/BF00410276)

Nelson GM, Prapapanich V, Carrigan PE, Roberts PJ, Riggs DL \& Smith DF 2004 The heat shock protein 70 cochaperone hip enhances functional maturation of glucocorticoid receptor. Molecular Endocrinology 18 1620-1630. (doi:10.1210/me.2004-0054)

Nicod N, Giusti V, Besse C \& Tappy L 2003 Metabolic adaptations to dexamethasone-induced insulin resistance in healthy volunteers. Obesity Research 11 625-631. (doi:10.1038/oby.2003.90)

Novelli M, De Tata V, Bombara M, Lorenzini A, Masini M, Pollera M, Bergamini E \& Masiello P 1999 Insufficient adaptive capability of pancreatic endocrine function in dexamethasone-treated ageing rats. Journal of Endocrinology 162 425-432. (doi:10.1677/joe.0.1620425)

Ogawa A, Johnson JH, Ohneda M, McAllister CT, Inman L, Alam T \& Unger RH 1992 Roles of insulin resistance and $\beta$-cell dysfunction in 
dexamethasone-induced diabetes. Journal of Clinical Investigation 90 497-504. (doi:10.1172/JCI115886)

Olefsky JM, Johnson J, Liu F, Jen P \& Reaven GM 1975 The effects of acute and chronic dexamethasone administration on insulin binding to isolated rat hepatocytes and adipocytes. Metabolism 24 517-527. (doi:10.1016/0026-0495(75)90076-1)

Origuchi T, Yamaguchi S, Inoue A, Kazaura Y, Matsuo N, Abiru N, Kawakami A \& Eguchi K 2011 Increased incidence of pre-diabetes mellitus at a department of rheumatology: a retrospective study. Modern Rheumatology 21 495-499. (doi:10.3109/s10165-011-0433-8)

Ortsäter H, Sjöholm A, Rafacho A 2012 Regulation of glucocorticoid receptor signaling and the diabetogenic effects of glucocorticoid excess. In State of the Art of Therapeutic Endocrinology, pp 1-28. Ed. Magdeldin S. Rijeka, Croatia: InTech.

Otto B, Tschöp M, Heldwein W, Pfeiffer AF \& Diederich S 2004 Endogenous and exogenous glucocorticoids decrease plasma ghrelin in humans. European Journal of Endocrinology 151 113-117. (doi:10.1530/eje.0. 1510113)

Ottosson M, Vikman-Adolfsson K, Enerbäck S, Olivecrona G \& Björntorp P 1994 The effects of cortisol on the regulation of lipoprotein lipase activity in adipose tissue. Journal of Clinical Endocrinology 79 820-825.

Pagano G, Cavallo-Perin P, Cassader M, Bruno A, Ozzello A, Masciola P, Dall'omo AM \& Imbimbo B 1983 An in vivo and in vitro study of the mechanism of prednisone-induced insulin resistance in healthy subjects. Journal of Clinical Investigation 72 1814-1820. (doi:10.1172/JCI111141)

Papachristou DN, Liu JL \& Patel YC 1994 Glucocorticoids regulate somatostatin peptide and steady state messenger ribonucleic acid levels in normal rat tissues and in a somatostatin-producing islet tumor cell line (1027B2). Endocrinology 134 2259-2266.

Patel R, Patel M, Tsai R, Lin V, Bookout AL, Zhang Y, Magomedova L, Li T, Chan JF, Budd C et al. 2011 LXR $\beta$ is required for glucocorticoid-induced hyperglycemia and hepatosteatosis in mice. Journal of Clinical Investigation 121 431-441. (doi:10.1172/JCI41681)

Pedersen SB, Jonler M \& Richelsen B 1994 Characterization of regional and gender differences in glucocorticoid receptors and lipoprotein lipase activity in human adipose tissue. Journal of Clinical Endocrinology $\mathbf{7 8}$ 1354-1359.

Petersons CJ, Mangelsdorf BL, Jenkins AB, Poljak A, Smith MD, Greenfield JR, Thompson CH \& Burt MG 2013 Effects of low-dose prednisolone on hepatic and peripheral insulin sensitivity, insulin secretion, and abdominal adiposity in patients with inflammatory rheumatologic disease. Diabetes Care 36 2822-2829. (doi:10.2337) dc12-2617)

Pieber TR, Stein DT, Ogawa A, Alam T, Ohneda M, McCorkle K, Chen L, McGarry JD \& Unger RH 1993 Amylin-insulin relationships in insulin resistance with and without diabetic hyperglycemia. American Journal of Physiology 265 E446-E453.

Pratt WB, Morishima Y, Murphy M \& Harrell M 2006 Chaperoning of glucocorticoid receptors. Handbook of Experimental Pharmacology 172 111-138.

Prummel MF, Wiersinga WM, Lips P, Sanders GT \& Sauerwein HP 1991 The course of biochemical parameters of bone turnover during treatment with corticosteroids. Journal of Clinical Endocrinology 72 382-386. (doi:10.1210/jcem-72-2-382)

Quesada I, Tudurí E, Ripoll C \& Nadal A 2008 Physiology of the pancreatic $\alpha$-cell and glucagon secretion: role in glucose homeostasis and diabetes. Journal of Endocrinology 199 5-19. (doi:10.1677/JOE-08-0290)

van Raalte DH, Ouwens DM \& Diamant M 2009 Novel insights into glucocorticoid-mediated diabetogenic effects: towards expansion of therapeutic options? European Journal of Clinical Investigation 39 81-93. (doi:10.1111/j.1365-2362.2008.02067.x)

van Raalte DH, Nofrate V, Bunck MC, van Iersel T, Elassaiss Schaap J, Nässander UK, Heine RJ, Mari A, Dokter WH, Dokter M et al. 2010 Acute and 2-week exposure to prednisolone impair different aspects of $\beta$-cell function in healthy men. European Journal of Endocrinology 162 729-735. (doi:10.1530/EJE-09-1034) van Raalte DH, Kwa KA, van Genugten RE, Tushuizen ME, Holst JJ, Deacon CF, Karemaker JM, Heine RJ, Mari A \& Diamant M 2013 Islet-cell dysfunction induced by glucocorticoid treatment: potential role for altered sympathovagal balance? Metabolism 62 568-577. (doi:10.1016/ j.metabol.2012.10.007)

Rafacho A, Giozzet VA, Boschero AC \& Bosqueiro JR 2008 Functional alterations in endocrine pancreas of rats with different degrees of dexamethasone-induced insulin resistance. Pancreas 36 284-293. (doi:10.1097/MPA.0b013e31815ba826)

Rafacho A, Cestari TM, Taboga SR, Boschero AC \& Bosqueiro JR 2009 High doses of dexamethasone induce increased $\beta$-cell proliferation in pancreatic rat islets. American Journal of Physiology. Endocrinology and Metabolism 296 E681-E689. (doi:10.1152/ajpendo.90931.2008)

Rafacho A, Marroquí L, Taboga SR, Abrantes JL, Silveira LR, Boschero AC, Carneiro EM, Bosqueiro JR, Nadal A \& Quesada I 2010a Glucocorticoids in vivo induce both insulin hypersecretion and enhanced glucose sensitivity of stimulus-secretion coupling in isolated rat islets. Endocrinology 151 85-95. (doi:10.1210/en.2009-0704)

Rafacho A, Quallio S, Ribeiro DL, Taboga SR, Paula FM, Boschero AC \& Bosqueiro JR $2010 b$ The adaptive compensations in the endocrine pancreas from glucocorticoid-treated rats are reversible after the interruption of treatment. Acta Physiologica 200 223-235. (doi:10.1111/ j.1748-1716.2010.02146.x)

Rafacho A, Abrantes JL, Ribeiro DL, Paula FM, Pinto ME, Boschero AC \& Bosqueiro JR 2011 Morphofunctional alterations in endocrine pancreas of short- and long-term dexamethasone-treated rats. Hormone and Metabolic Research 43 275-281. (doi:10.1055/s-0030-1269896)

Rafacho A, Gonçalves-Neto LM, Santos-Silva JC, Alonso-Magdalena P, Merino B, Taboga SR, Carneiro EM, Boschero AC, Nadal A \& Quesada I 2014 Pancreatic $\alpha$-cell dysfunction contributes to the disruption of glucose homeostasis and compensatory insulin hypersecretion in glucocorticoid-treated rats. PLOS ONE 9 e93531. (doi:10.1371/journal. pone.0093531)

Ratman D, Vanden Berghe W, Dejager L, Libert C, Tavernier J, Beck IM \& De Bosscher K 2013 How glucocorticoid receptors modulate the activity of other transcription factors: a scope beyond tethering. Molecular and Cellular Endocrinology 380 41-54. (doi:10.1016/j.mce.2012.12.014)

Raúl Ariza-Andraca C, Barile-Fabris LA, Frati-Munari AC \& BaltazárMontufar P 1998 Risk factors for steroid diabetes in rheumatic patients. Archives of Medical Research 29 259-262.

Rebuffé-scrive M, Walsh UA, McEwen B \& Rodin J 1992 Effect of chronic stress and exogenous glucocorticoids on regional fat distribution and metabolism. Physiology \& Behavior 52 583-590.

Reynolds RM, Labad J, Sears AV, Williamson RM, Strachan MW, Deary IJ, Lowe GD, Price JF, Walker BR \& Edinburgh Type 2 Diabetes Study Investigators 2012 Glucocorticoid treatment and impaired mood, memory and metabolism in people with diabetes: the Edinburgh Type 2 Diabetes Study. European Journal of Endocrinology 166 861-868. (doi:10.1530/EJE-12-0041)

Rizza RA, Mandarino LJ \& Gerich JE 1982 Cortisol-induced insulin resistance in man: impaired suppression of glucose production and stimulation of glucose utilization due to a postreceptor detect of insulin action. Journal of Clinical Endocrinology 54 131-138. (doi:10.1210/jcem54-1-131)

Roma LP, Oliveira CA, Carneiro EM, Albuquerque GG, Boschero AC \& Souza KL $2011 \mathrm{~N}$-acetylcysteine protects pancreatic islets against glucocorticoid toxicity. Redox Report 16 173-180. (doi:10.1179/ 1351000211Y.0000000006)

Rooney DP, Neely RD \& Cullen C 1993 The effect of cortisol on glucose/glucose-6-phosphate cycle activity and insulin action. Journal of Clinical Endocrinology 77 1180-1183.

Saad MJ, Folli F, Kahn JA \& Kahn CR 1993 Modulation of insulin receptor, insulin receptor substrate-1, and phosphatitidylinositol 3-kinase in liver and muscle of dexamethasone-treated rats. Journal of Clinical Investigation 92 2065-2072. (doi:10.1172/JCI116803) 
Schäcke H, Döcke WD \& Asadullah K 2002 Mechanisms involved in the side effects of glucocorticoids. Pharmacology \& Therapeutics 96 23-43.

Schneiter P \& Tappy L 1998 Kinetics of dexamethasone-induced alterations of glucose metabolism in healthy humans. American Journal of Physiology 275 E806-E813.

Shao J, Qiao L \& Friedman JE 2004 Prolactin, progesterone, and dexamethasone coordinatley and adversely regulate glucokinase and cAMP/PDE cascades in MIN6 $\beta$-cells. American Journal of Physiology. Endocrinology and Metabolism 286 E304-E310. (doi:10.1152/ajpendo. 00210.2003)

Short KR, Bigelow ML \& Nair KS 2009 Short-term prednisone use antagonizes insulin's anabolic effect on muscle protein and glucose metabolism in young healthy people. American Journal of Physiology. Endocrinology and Metabolism 297 E1260-E1268. (doi:10.1152/ajpendo.00345.2009)

Slavin BG, Ong JM \& Kern PA 1994 Hormonal regulation of hormonesensitive lipase activity and mRNA levels in isolated rat adipocytes. Journal of Liposome Research 35 1535-1541.

van Staa TP, Leufkens HG, Abenhaim L, Begaud B, Zhang B \& Cooper C 2000 Use of oral corticosteroids in the United Kingdom. Quarterly Journal of Medicine 93 105-111. (doi:10.1093/qjmed/93.2.105)

Stahn C \& Buttgereit F 2008 Genomic and nongenomic effects of glucocorticoids. Nature Clinical Practice. Rheumatology 4 525-533. (doi:10.1038/ncprheum0898)

Stojanovska L, Rosella G \& Proietto J 1990 Evolution of dexamethasoneinduced insulin resistance in rats. American Journal of Physiology $\mathbf{2 5 8}$ E748-E756.

Strehl C \& Buttgereit F 2013 Optimized glucocorticoid therapy: teaching old drugs new tricks. Molecular and Cellular Endocrinology 380 32-40. (doi:10.1016/j.mce.2013.01.026)

Strehl C \& Buttgereit F 2014 Unraveling the functions of the membranebound glucocorticoid receptors: first clues on origin and functional activity. Annals of the New York Academy of Sciences 1318 1-6. (doi:10.1111/nyas.12364)

Swali A, Walker EA, Lavery GG, Tomlinson JW \& Stewart PM 2008 $11 \beta$-Hydroxysteroid dehydrogenase type 1 regulates insulin and glucagon secretion in pancreatic islets. Diabetologia 51 2003-2011. (doi:10.1007/s00125-008-1137-2)

Tauber U, Haack D, Nieuweboer B, Kloss G, Vecsei P \& Wendt H 1984 The pharmacokinetics of fluocortolone and prednisolone after intravenous and oral administration. International Journal of Clinical Pharmacology, Therapy, and Toxicology 22 48-55.

Thiele K, Buttgereit F, Huscher D, Zink A \& Germany Collaborative Arthritis Center 2005 Current use of glucocorticoids in patients with rheumatoid arthritis in Germany. Arthritis and Rheumatism 53 740-747. (doi:10.1002/art.21467)

Thomas CR, Turner SL, Jefferson WH \& Bailey CJ 1998 Prevention of dexamethasone-induced insulin resistance by metformin. Biochemical Pharmacology 56 1145-1150. (doi:10.1016/S0006-2952(98)00151-8)
Ullrich S, Berchtold S, Ranta F, Seebohm G, Henke G, Lupescu A, Mack AF, Chao CM, Su J, Nitschke R et al. 2005 Serum- and glucocorticoidinducible kinase 1 (SGK1) mediates gluocorticoid-induced inhibition of insulin secretion. Diabetes 54 1090-1099. (doi:10.2337/diabetes.54.4.1090)

Vandevyver S, Dejager L, Tuckermann J \& Libert C 2013 New insights into the anti-inflammatory mechanisms of glucocorticoids: an emerging role for glucocorticoid-receptor-mediated transactivation. Endocrinology 154 993-1007. (doi:10.1210/en.2012-2045)

Vila G, Krebs M, Riedl M, Baumgartner-Parzer SM, Clodi M, Maier C, Pacini G \& Luger A 2010 Acute effects of hydrocortisone on the metabolic response to a glucose load: increase in the first-phase insulin secretion. European Journal of Endocrinology 163 225-231. (doi:10.1530/EJE-10-0282)

Voice MW, Seckl JR, Edwards CR \& Chapman KE 1996 11ß-hydroxysteroid dehydrogenase type 1 expression in $2 S$ FAZA hepatoma cells is hormonally regulated: a model system for the study of hepatic glucocorticoid metabolism. Biochemical Journal 317 621-625.

Wajngot A, Khan A, Giacca A, Vranic M \& Efendic S 1990 Dexamethasone increases glucose cycling, but not glucose production, in healthy subjects. American Journal of Physiology 259 E626-E632.

Wajngot A, Giacca A, Grill V, Vranic M \& Efendic S 1992 The diabetogenic effects of glucocorticoids are more pronounced in low- than in highinsulin responders. PNAS 89 35-6039. (doi:10.1073/pnas.89.13.6035)

Walker BR, Campbell JC, Fraser R, Stewart PM \& Edwards CR 1992 Mineralocorticoid excess and inhibition of 11- $\beta$-hydroxysteroid dehydrogenase in patients with ectopic ACTH syndrome. Clinical Endocrinology 37 483-492. (doi:10.1111/j.1365-2265.1992.tb01478.x)

Westermark P, Andersson A \& Westermark GT 2011 Islet amyloid polypeptide, islet amyloid, and diabetes mellitus. Physiological Reviews 91 795-826. (doi:10.1152/physrev.00042.2009)

Wierup N, Sundler F \& Heller RS 2013 The islet ghrelin cell. Journal of Molecular Endocrinology 19 R35-R49. (doi:10.1530/JME-13-0122)

Willi SM, Kennedy A, Wallace P, Ganaway E, Rogers NL \& Garvey WT 2002 Troglitazone antagonizes metabolic effects of glucocorticoids in humans: effects on glucose tolerance, insulin sensitivity, suppression of free fatty acids, and leptin. Diabetes 51 2895-2902. (doi:10.2337/ diabetes.51.10.2895)

Wilson CG, May CS \& Paterson JW 1977 Plasma prednisolone levels in man following administration in plain and enteric-coated forms. British Journal of Clinical Pharmacology 4 351-355. (doi:10.1111/j.1365-2125. 1977.tb00723.x)

Wise JK, Hendler R \& Felig P 1973 Evaluation of $\alpha$-cell function by infusion of alanine in normal, diabetic and obese subjects. New England Journal of Medicine 288 487-490. (doi:10.1056/NEJM197303082881003)

Zawalich WS, Tesz GJ, Yamazaki H, Zawalich KC \& Philbrick W 2006 Dexamethasone suppresses phospholipase $\mathrm{C}$ activation and insulin secretion from isolated rat islets. Metabolism 55 35-42. (doi:10.1016/ j.metabol.2005.06.023)

Received in final form 2 September 2014

Accepted 30 September 2014

Accepted Preprint published online 30 September 2014 http://joe.endocrinology-journals.org DOI: 10.1530/JOE-14-0373
(C) 2014 Society for Endocrinology Printed in Great Britain
Published by Bioscientifica Ltd. 